\title{
An Indonesian National English Textbook for Secondary Level: Is It Qualified Enough?
}

\author{
Susiati(1) \\ Universitas Muhammadiyah Surakarta \\ sus249@ums.ac.id \\ Elok Mufidati(2) \\ Universitas Muhammadiyah Surakarta \\ Elokmufidati21@gmail.com
}

DOI: 10.23917/varidika.v32i1.11511

\begin{abstract}
Submission
ABSTRACT

Track:

Received:

20 March 2020

Final Revision:

20 April 2020

Available online:

31 June 2020

Corresponding

Author:

Susiati (1)

sus249@ums.ac.id

Elok Mufidati (2)

Elokmufidati21@gmail.com

This study describes how a national English textbook entitled When English Rings a Bell for Junior High School Level meets criteria of Cunnignsworth's good English textbook. Interviews with the teacher and students of grade VII at SMP Muhammadiyah 10 Surakarta were conducted to investigate how the textbook is considered qualified. Document review was also applied to analyse the textbook. The results show that all chapters in the "When English Rings a Bell" textbook fulfill the Cunningsworth's criteria of a good textbook. The textbook was suitable enough to be used for media in teaching learning process for the seventh grade students of Junior High School. From the teacher's view, the textbook is appropriate with the learning objectives of the current curriculum. This is in line with the Cunningsworth's criteria. However, some students found difficulties in using this textbook: 1). they still need teacher's role to clearly explain the materials, 2). Supporting materials from other sources to improve the students' ability in both comprehending the concept and doing practices. These two may be caused by the lack of examples in the textbook.
\end{abstract}

Keywords: evaluation, textbook, cunningsworth theory 


\section{INTRODUCTION}

English has long become a language for international communication. English is widely used in international meetings such as conferences, inter-state agreements, and academic meetings. That is why; people from different countries have been competing to achieve high level fluency in English. As a foreign language, English has been years taught in high schools in Indonesia. In this level, since 19th century the Government has inserted English as a compulsory subject. Thus, the government can acquire knowledge and technology to build this country. Richards (1985: 2) states that "in countries where English is not an official language it may still have a significant role to play. It may be an important school subject and it may be necessary to pass an examination in English to enter a university. It may be the language of certain courses at a university, or at least of a large percentage of the students ${ }^{\text {ee }}$ textbooks. Some work areas such as tourism, hotel may need good English for communication with customers as part of good service.

Some factors in the teaching and learning process lead to the outcomes of students' learning. These factors go through pre-, while- and post- teaching activities. This is where a teacher should take their role to formulate the syllabus, materials and techniques of teaching in the classroom. Richards (2001: 1) argues that "teaching materials are key component in most language programs. Whether the teacher uses a textbook, institutional prepared material or make use of his or her own materials, instructional materials generally serve as the basis for much of the language input learners receive and the language practice that occurs in the classroom". One medium in learning English is a textbook.

Cunningsworth (1984) suggests that textbook is a book used for teaching situations written by experts which is examined for appropriateness before being used or published. Many countries including Indonesia have been years using textbooks in education especially in schools. It means that the textbook used in schools is officially issued by the Government as a national-compulsory book used by teachers and students. This is, somehow, important as a national guideline as texts, activities and explanations are provided in a textbook used as classroom lessons (Hutchinson and Torres (1994). That is why, Harmer (2007) would agree with this idea since he says both teachers and students will get benefits from using textbook in the classroom.

O’Neill (1982) has previously highlighted that there are some benefits of using a textbook. First, although a textbook is not specially designed for particular students, most parts 
of its materials are compatible with students' needs. Second, students will find it easier to review the lessons having been discussed in the classroom and learn the future materials prior to the meeting in the classroom. Third, with reasonable price a textbook provides high quality materials that students can afford for. Finally, teachers can also adjust textbooks to the learners' needs by adapting and modifying them and make interaction of issued to happen.

It can be observed that teachers indeed need textbooks. Textbooks become an important thing in the class for teaching and learning process because a textbook is a written source designed for materials to be taught in the classroom to increase the knowledge and experience of learners.. "Textbook are best seen as a source in achieving aims and objectives that have been set in terms of learner needs" (Cunningsworth, 1995: 7). Thus, textbook is one source of materials in teaching learning process.

As one important medium in teaching and learning activities in the classroom, a textbook must satisfy some qualities. The following are the criteria of a good textbook as suggested by Cunningsworth (1995: 15-17):

“a) textbooks should correspond to the learner's needs, b) textbooks should match with the aims and objectives of the language -learning program, c) textbooks should reflect the use (present or future) which learners will make of the language. Textbooks should be chosen that will help equip students to use language effectively for their own purposes. d) textbooks should take account students' needs as learners and should facilitate their learning processes, without dogmatically imposing a rigid "method", e) textbooks should have a clear role as a support for learning. like teachers, they mediate between the target language and the learner."

Pursuant to this, a textbook should be suitable with the curriculum and address the learners' needs. Recently, many textbooks in Indonesia become controversial. They bring up some issues such as porn contents, LGBT issues, divorce matters which are today blown up in national mainstream media. This causes worries of society especially parents. Unfortunately, teachers sometimes just realize these kinds of contents in a textbook in while-teaching in the classroom.

An English textbook entitled "When English Rings a Bell” is issued by the Indonesian Government which is by far considered a 'safe' textbook from pornography, violent and LGBT contents. However, this textbook needs to be investigated whether all parts of the book have met criteria of a good textbook. Using Hutchinson's (1995) criteria of a good English textbook, 
this article describes whether the national English textbook has been designed for good quality especially for VIII class of Junior High School.

\section{RESEARCH METHOD}

The type of this research is a descriptive qualitative research. The researchers collected the data, made analysis and finally made a conclusion. The object of this study is an English textbook for Grade VIII students and a teacher of Junior High School entitled Bahasa Inggris "When English Rings a Bell". Content analysis was employed to analyse the textbook. The participants of this study were an English teacher and six students from different classes of Grades VIII of SMP Muhammadiyah 10 Surakarta. This research applied document review and interview as the data source.

\section{RESULTS \& DISCUSSION}

In the When English Rings a Bell textbook, learning objectives are written in the beginning of each chapter. This matches with both the national curriculum and the language learning program at SMP/MTs students. The School standard of competence for class VIII is that the students are able to understand and variety of short and functional texts for both monologue and essay in descriptive, narrative and recount texts. The use of vocabulary, grammar and rhetorical steps show the level of materials. The findings show that the objective of Chapter I until Chapter XIII confirms with the objectives of English teaching learning for SMP/MTs as stated in its standard of competence. The objective is arranged well through each Chapter. Chapter I is "It is English Time"; Chapter II is "We can do it, and we will do it" ; Chapter III is "We know what to do"; Chapter IV is "Come to my birthday, please!"; Chapter $\mathrm{V}$ is "I'm so happy for you!"; Chapter VI is "Our busy roads"; Chapter VII is "My uncle is a zookeeper"; Chapter VIII is "What are you doing?"; Chapter IX is "Bigger is not always better"; Chapter X is "When I was a child"; Chapter XI is "Yes, we made it"; Chapter XII is "Don't forget it, please!", and Chapter XIII is "We got a lot of histories". Furthermore, the themes or topics are also shown on the same page with the learning objectives in each chapter of the textbook. Exercises and tables also make the students easy to learn English and justify their ability in English. The content of materials of the textbook matches with the curriculum 2013 
although the textbook is improvised with the discussion of one sub-topic in each chapter. Different from the same textbook for grade VII, Hapsari (2017) examined the percentage of appropriateness of the textbook with the Cunningsworth's criteria. The result suggests that the impressionistic/surface textbook analysis is scored with $70 \%$ and the in-depth textbook analysis is summed with $60 \%$. It means the When English Rings a Bell textbook for grade VII is good enough to be used as a source of materials in the teaching and learning process in the classroom. For the textbook series for grade VII is qualified because at least it follows the Cunningsworth's first criterion of a good English textbook.

For the second criterion, a good textbook should be designed to help develop students to use language effectively based on their own purposes. When English Rings a Bell matches with Generic Competence number 3.7 in the national curriculum should employ the social function, text structure, and mechanics on spoken and written forms of transactional interaction texts. These include some actions: giving and asking for information based on the situation given for general fact. It emphasizes on the use of simple present tense). Whereas, Generic Competence number 4.7 includes brief and simple transactional interaction both in spoken and written form which applies the actions such as asking and giving information related to the context, its social function, generic structure and the mechanics according to the context given.

Related to this, the researchers found that textbook shows elements of language structure namely simple present tense, present future tense $(\mathrm{s}+$ will + object + complement $)$; present perfect tense $(\mathrm{s}+$ have/has $+\mathrm{V} 3)$; present continuous tense $(\mathrm{s}+$ be $(\mathrm{am} / \mathrm{is} /$ are $)+$ present participle-ing); simple past tense $(\mathrm{S}+\mathrm{V} 2+\mathrm{O})$; and past continuous tense ( $\mathrm{s}+\mathrm{be}(\mathrm{am} / \mathrm{is} / \mathrm{are})+$ present participle-ing). These different types of tenses are written in conversation between teacher with students and students with students. It means that the textbook "When English Rings a Bell" teaches students English in use. It is practical, not theoretical. The layout of the content is also well designed so that it interests students' motivation to learn through the materials in the textbook. The learning objectives are written in every beginning of sub chapter. The students are, that is why, informed what they are going to learn with in the chapter. The dialogue and monologue are placed in different space or sections. The exercise is embedded in the explanation of a concept in every chapter. It leads to the improvement of students' understanding on the material being learned. In the end of every chapter, there is a sheet of students' activity logs to record what the students' have learned and they have been able to do. This result is in line with Arba'ati's research (2015) stating that grammatical rules in this 
textbook can be seen from the conversations, pictures, exercises in table form. She also mentions that there is a journal, notice of lessons, that refers to speaking, writing and reading skills in the end of the chapter. For speaking skill, the students are able to play a role based on the conversations and pictures. For writing skill, the students are able to create a list to do in the table form in the exercises. Finally, the students are also able to observe the dialogues before they practice to play the role.

In the third criterion, a good textbook should take account students' needs as leaners and should facilitate their learning processes, without dogmatically imposing a rigid "method". "When English Rings a Bell” textbook provides students' needs based on their level of mastery. The learning activities in this textbook are layouted in good, varied and gradual design to motivate learners to learn more. These are developed with the dialogues or conversations, pictures improving speaking and writing skills. These learning activities characterize Indonesian people as they perform Indonesian cultures. Furthermore, several chapters contain song lyrics. It is shown by the instruction is "We will say the words loudly, clearly, and correctly". It is also found that the activities and tasks in the "When English Rings a Bell" textbook are basically communicative. It consistently promotes balance activities between concept or explanation and practices. This is positive since a concept accompanied with practices can actualize learners' ability in language skills and trigger creativity, capable and freer personality to learners.

According to the fourth criterion, a good textbook should have a clear role as a support for learning. They mediate between the target language and the learners as a teacher does. In the "When English Rings a Bell (Teacher's Book)" textbook, a teacher plays role as a controller of activities in the classroom. The textbook contains guidelines for teachers about what to teach and what to do in the classroom. The textbook also includes observation sheets for the teacher in every chapter. Thus, the teacher can monitor the students' activities and make assessment for the students. In short, the "When English Rings a Bell" textbook illuminates each role of a teacher, students, classroom procedure, classroom activities, and media. Similar to the result by Safitri (2014), it is found that the textbooks do not promote either the vocabulary building or grammar exercise. In which, it is a proof that this finding agrees with Tomlinson (2008) stating 
that textbooks help the learners make full use of the language experience available to them outside the classroom.

Based on the discussion, the in-depth textbook analysis shows that all chapters in the "When English Rings a Bell” textbook satisfy all criteria Cunningsworth's standardized criteria of a good textbook. Consequetnly, the textbook is appropriate to be used for the eighth grade students of Junior High School for the learning activities in the classroom.

\section{CONCLUSION}

"When English Rings a Bell" satisfies the Cunningsworth's first criterion of a good textbook that the textbook contains aims and objectives of learning. The textbook also comprises varsities of language structures which help equip the students to practice language in use and in purpose. This matches with Cunningworth's second criterion. For the third criterion, a good textbook should meet students' needs as leaners and help improve their learning processes, with flexibly emphasizing various methods. "When English Rings a Bell” textbook fulfil the students' needs as learners with different types of learning activities. Finally, the fourth criterion suggests that a good textbook should involve a clear role as a support for learning. Like teachers, they facilitate the target language and the learners' needs. The in-depth textbook analysis shows that all chapters in the "When English Rings a Bell" textbook meet criteria from Cunningsworth standard requirement. Thus, the textbook is appropriate to be used for media in teaching learning process for the seventh grade students of Junior High School.

\section{REFERENCES}

Amrina. 2018. An Analysis of "Bahasa Inggris" Textbook Used in the Second Grade of Senior High School. Thesis. UIN Ar-Raniry Banda Aceh.

Arba'ati, Rani. 2015. An Analysis On English Textbook Entitled Bahasa Inggris "When English Rings A Bell” For the Eight year Students Of Junior High School Based on the 2013 Curriculum. Thesis. Universitas Muhammadiyah Surakarta.

Cunningsworth, A. 1984. Evaluating and Selecting EFL Teaching Materials. London: Heinemann Educational.

Cunningsworth, A. 1995. Choosing your Coursebook. Cambridge: Macmillan Heinemann.

Faisal. 2014. Teachers' perception toward english students' textbooks used at school. Thesis. UIN Ar-Raniry. 
Hapsari, Ika Ayu. 2017. A Content Analysis of “When English Rings a Bell” English Textbook in 2013 Curriculum for the Seventh Grade Student of Junior High School Published by Kementrian Pendidikan dan Kebudayaan Republik Indonesia. Thesis. English Education Department. Islamic Education and Teacher Training Faculty. State Islamic Institute of Surakarta.

Harmer, J. 2007. The Practice of English Language Teaching. Harlow: Longman.

Hutchinson, Tom and Torres, Eunice. 1994. The textbook as agent of change. ELT Journal, Vol. 48, Issue 4, pp. 315-328.

Lathif, Masyhudi. 2015. An Evaluation of English Textbookks for the Eight Graders of Junior Highschool. Thesis. Universitas Negeri Yogyakarta.

Ramazani, Milad. 2013. Teachers' Perceptions of Using English Textbooks for Iranian Technical and Vocational College Students. Procedia: Social and Behavioral Sciences, No.70, pp.1748-1762.

Richards, J. C. 1985. The Context of Language Teaching. Cambridge: Cambridge University.

Richards, J. C. 2001. Curriculum Development in Language Education. Cambridge: Cambridge University Press.

Safitri, Iis. 2014. An Analysis of Reading Materials on the Quality of English Textbook "Headline English" Published by Sewu for Grade VII Students of Junior High School. Thesis. Universitas Negeri Yogyakarta.

Suryana. 2017. Manajemen Kelas Berkarakteristik Siswa. Edukasi Islami Jurnal Pendidikan Islam, Vol.1, No.2, pp.11-22.

Tarigan, H.G. 1993. Strategi Pengajaran dan Pembelajaran Bahasa. Bandung: Angkasa.

Tomlinson, Brian. 2012. Material Development in Language Teaching (2nd Ed.). Cambridge: Cambridge University Press. 